Vol. 44, N. 3 : pp. $233-238$, September, 2001

ISSN 1516-8913 Printed in Brazil

\title{
Evaluation of Arsenic and Selenium in Brazilian Soluble Coffee by Inductively Coupled Plasma Atomic Emission Spectrometry with Hydride Generation
}

\author{
Éder José dos Santos ${ }^{1 *}$ and Elisabeth de Oliveira ${ }^{2}$ \\ ${ }^{1}$ Instituto de Tecnologia do Paraná (TECPAR), CP 357, CEP 81310-020, Curitiba, PR, Brazil; ${ }^{2}$ Universidade de \\ São Paulo (USP), Instituto de Química, CP 26077,CEP 05508-900, SP, Brazil
}

\begin{abstract}
A method for the evaluation of arsenic and selenium in soluble coffee by inductively coupled plasma atomic emission spectrometry with continuous hydride generation to attend the Brazilian food legislation is described. Samples were digested with nitric acid and hydrogen peroxide in a focused microwave system. Slow heating eliminated nitric acid and selenium (VI) was reduced to selenium (IV) by addition of 6 mol/L hydrochloric acid and heating at $90^{\circ} \mathrm{C}$ under a reflux system. The influence of sample acidity on sensitivity was investigated. Hydrochloric acid $6 \mathrm{~mol} / \mathrm{L}$ was the most suitable reaction medium. Practical detection limits of 2.0 $\mathrm{\mu g} / \mathrm{L}$ for As and $1.0 \mu \mathrm{g} / \mathrm{L}$ for Se were achieved and attended the Brazilian food legislation. The results of recoveries on spiked samples demonstrate the reliability and accuracy of the procedure.
\end{abstract}

Key words: ICP-AES, As, Se, soluble coffee

\section{INTRODUCTION}

The production of Brazilian soluble coffee is almost entirely destined for exportation that was estimated to be 62 thousand tons in 1995 (Silva, 1996). The determination of macronutrients, micronutrients and toxic elements in soluble coffee is of great general interest, particularly because of the importance of coffee in nutrition to millions of people around the world (Krivan et al., 1982). Previous work on the composition of coffee and its products is mainly concerned with the mineral contents and studies on toxic elements are scarcely reported (Clarke et al., 1974; Gillies et al., 1983; Horwitz et al., 1974; Kuennen et al., 1982; Kapur et al., 1974; Koch et al., 1989; Lara et al., 1975/76). No information exists on the content of arsenic and selenium in this product although a number of publications (Goulden et al., 1981; Nakahara et al., 1985; Nakahara, 1981; Nygaard et al., 1982; Oliveira et al., 1983; Pahlavanpour et al., 1980; Ybanez et al., 1992) demonstrated that hydride generation, followed by introduction of gaseous hydrides into an ICP was a suitable method for the determination of several trace elements, including arsenic and selenium, for which detection limits were inadequate for foods and related matrices when conventional pneumatic nebulization was used. The objective of this work was to develop a method for the evaluation of arsenic and selenium in soluble coffee by inductively coupled plasma atomic emission spectrometry with hydride generation in order to attend the Brazilian food legislation. The influence of sample acidity on sensitivity of the method was also studied.

\footnotetext{
${ }^{*}$ Author for correspondence
} 


\section{MATERIALS AND METHODS}

Reagents: Distilled and deionized water (deionizing Permution); arsenic (V) and selenium (IV) stock standard solutions (1000 $\mu \mathrm{g} / \mathrm{mL})$ (Titrisol Merck); nitric acid, (Merck), 65\%; hydrogen peroxide, (Merck), 30\%; hydrochloric acid, (Merck), 37\%, use of a $6 \mathrm{~mol} / \mathrm{L}$ solution; Sodium borohydride, (Merck), $99.9 \%$, use of a $1 \% \mathrm{w} / \mathrm{v}$ solution in 0.1 $\mathrm{mol} / \mathrm{L} \mathrm{NaOH}$.

Apparatus : Focused microwave system model 7400 Spex with $250 \mathrm{~mL}$ glass tubes; hydride generation was carried out in a continuous mode by using a two-channels peristaltic pump (Gilson Instrument Co., Minipuls) to introduce sample and borohydride reagent to a phase separator from Oliveira et al., 1983 (Figure 1). The operating conditions for hydride generation system are summarized in Table 1. A Baird PSX sequencial ICP spectrometer with a focal lengh Czerny-Turner monochromator, a holografic grating with a linear dispersion of $0.74 \mathrm{~nm} / \mathrm{mm}$ (first order), a spectral resolution of $0.014 \mathrm{~nm}$ and a RF generator of 2.3
$\mathrm{kW}$ at $40.68 \mathrm{MHz}$ were employed. The operating conditions are also summarized in Table 1.

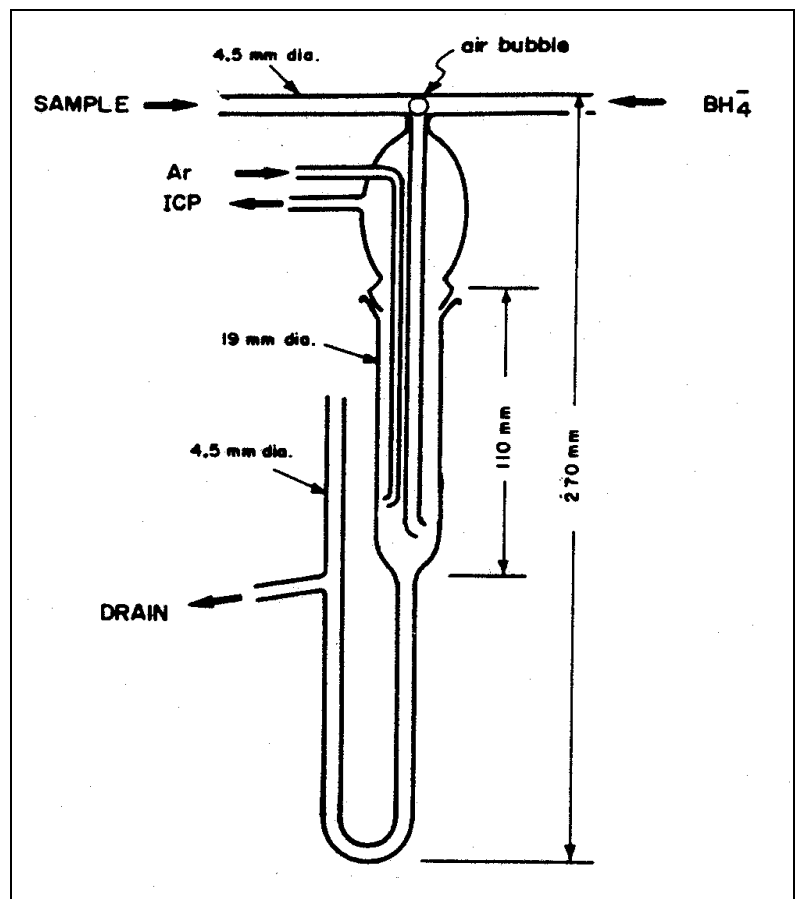

Figure 1 - Phase separator developed by Oliveira et al.,1983.

Table 1 - Standard operating conditions for the ICP and hydride-generation system.

\begin{tabular}{ll}
\hline PLASMA & \\
\hline Plasma gas flow & $8.5 \mathrm{~L} / \mathrm{min}$. \\
Auxiliary gas flow & $1.2 \mathrm{~L} / \mathrm{min}$. \\
Observation height & $12 \mathrm{~mm}$ above the load coil \\
Integration time & $5 \mathrm{ds}$ \\
Incident power & $1.0 \mathrm{~kW}$ \\
Reflected power & $<5 \mathrm{~W}$ \\
Analytical lines & $\mathrm{As}-193.696 \mathrm{~nm} ; \mathrm{Se}-196.026 \mathrm{~nm}$ \\
\hline HYDRIDE-GENERATION APPARATUS & \\
\hline Sample acidity & $6 \mathrm{~mol} / \mathrm{L} \mathrm{HCl}$ \\
Sample flow & $1.5 \mathrm{~mL} / \mathrm{min}$. \\
NaBH & flow \\
Carrier gas flow & $2.5 \mathrm{~mL} / \mathrm{min}$. \\
\hline
\end{tabular}

Standard solutions preparation and calibration curves : Calibration curves for the analytes arsenic (V) and selenium (IV) were made by using four different standard solutions: $0.0 \mu \mathrm{g} / \mathrm{L}$, $5.0 \mu \mathrm{g} / \mathrm{L}, 10.0 \mu \mathrm{g} / \mathrm{L}$ and $20.0 \mu \mathrm{g} / \mathrm{L}$ in $6 \mathrm{~mol} / \mathrm{L} \mathrm{HCl}$.
Sample preparation: Twenty-one samples of soluble coffee were collected from the Brazilian market and were used in the present work. Part one of sample preparation was developed in our laboratory (Santos et al.,1997), and part two was adapted from Brimmer et al.,1987.

Part one: Five gram of sample was introduced into a $250 \mathrm{~mL}$ glass tube (from the focused microwave 
system model 7400 SPEX) and $30 \mathrm{~mL}$ of $\mathrm{HNO}_{3}$ was added. After 30 minutes of initial reaction at ambient temperature, the glass tube was placed on the focused microwave system, heated at 105 W power for 5 minutes, and allowed to cool for 5 minutes. This heating and cooling procedures were repeated. Then $2.5 \mathrm{~mL}$ of $\mathrm{H}_{2} \mathrm{O}_{2}$ were added and the heating and cooling procedures were repeated once more.

Part two: The solution prepared above were transferred to a $100 \mathrm{~mL}$ boiling flask and evaporated at $90 \pm 5^{\circ} \mathrm{C}$ to almost dryness. Twentyfive $\mathrm{mL}$ of $6 \mathrm{~mol} / \mathrm{L} \mathrm{HCl}$ were added to this and the solution was heated at $90 \pm 5^{\circ} \mathrm{C}$ under reflux system for 30 minutes. Three replicate analyses were carried out.

Spiked samples: Volumes of the standard solutions containing $0.25 \mu \mathrm{g}$ of arsenic (V) and $0.25 \mu \mathrm{g}$ of selenium (IV) were added to $1 \mathrm{~g}$ of three samples (equivalent to $10.0 \mu \mathrm{g} / \mathrm{L}$ in the final solutions on which those analytes were determined). Two replicate analyses were carried out and these spiked samples were treated as described on sample preparation item (part one and two).

\section{RESULTS AND DISCUSSION}

\section{Optimization of operating parameters}

The phase separator constructed according to the specifications from Oliveira et al.,1983, (Figure 1), was used with few problems in the operating conditions of the PSX-Baird spectrometer. Flow rates of $0.6 \mathrm{~L} / \mathrm{min}$., used at conventional solution nebulization by pneumatic nebulizer, were also suitable for determination of arsenic and selenium by hydride generation. At flow rates below 0.6 $\mathrm{L} / \mathrm{min}$., the formation of hydrogen bubbles was high, hindering the perfect operation of the drain. On the other hand, at flow rates higher than 0.6 $\mathrm{L} / \mathrm{min}$., the back pressure created tended to force all the waste liquid out of the U-tube in the phase separator and usually extinguished the plasma. A concentration of $\mathrm{NaBH}_{4}$ more than $1 \% \mathrm{w} / \mathrm{v}$ also extinguished the plasma and at less than this value the signal was very poor (Oliveira et al.,1983). The effect of the hydrochloric acid concentration on sensitivity was studied. The following solutions were prepared:

- $100 \mathrm{~mL}$ of 1 to $7 \mathrm{~mol} / \mathrm{L} \mathrm{HCl}$ (solutions of the blank);

- $100 \mathrm{~mL}$ of standard solutions of $50.0 \mu \mathrm{g} / \mathrm{L}$ of As (V) and Se (IV) in 1 to $7 \mathrm{~mol} / \mathrm{L} \mathrm{HCl}$;

- $\quad 1 \% \mathrm{w} / \mathrm{v} \mathrm{NaBH}_{4}$ solution in $0.1 \mathrm{~mol} / \mathrm{L} \mathrm{NaOH}$.

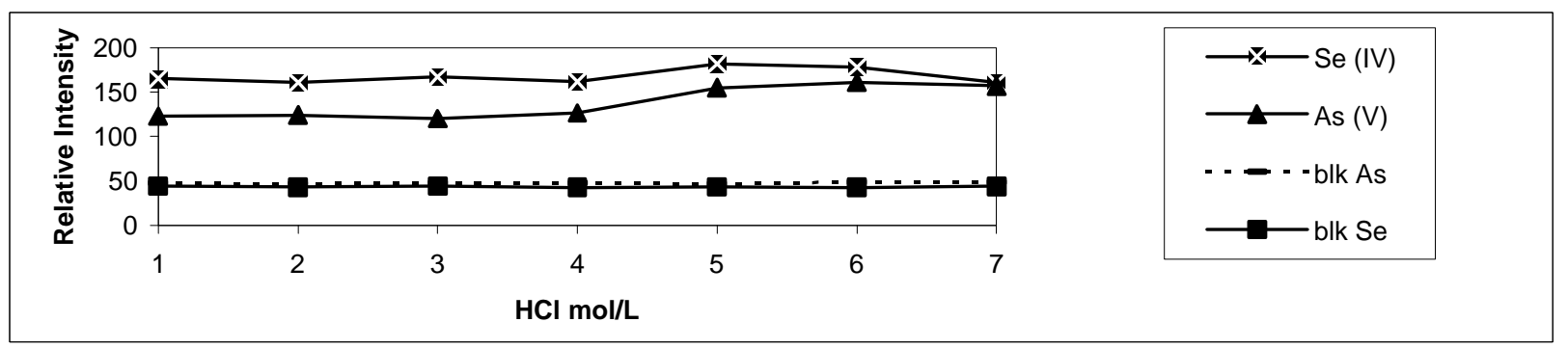

Figure 2 - Effect of the acid concentration on sensitivity.

Figure 2 shows a plot of the different $\mathrm{HCl}$ concentrations versus the relative intensity of the analytes arsenic (V) and selenium (IV).

The base line represented by blank solutions (blk) showed invariable values at different concentrations of hydrochloric acid. The response had the best sensibility for selenium and arsenic with 5 and $6 \mathrm{~mol} / \mathrm{L} \mathrm{HCl}$.

Linearity, instrumental detection limits and practical detection limits

The parameters of analytical curve and detection limits were investigated under the conditions detailed in Table 1 previously presented and are shown in Table 2. Typical calibrations were linear up to $20.0 \mu \mathrm{g} / \mathrm{L}$. The instrumental detection limit is defined as the concentration that produces a net line intensity equivalent to three times the standard deviation of the blank or background signal (Oliveira et al.,1983; Thompson, 1987). The blank was the ordinate intercept calculated from the linear regression analysis of the calibration data and showed in Table 2. However, under the conditions of this analysis, the background signal of the samples was different from that produced by the standard solutions and the blank, so the 
practical detection limits used in this work were greater than instrumental detection limits by a factor of 2 since these results were better and a more realistic estimate for quantitative analysis.

\section{Determination of arsenic and selenium}

The results obtained for the arsenic and selenium in twenty-one samples of Brazilian soluble coffee are presented in Table 3. The values were below the practical detection limits and were the following, in $\mu \mathrm{g} / \mathrm{g}$ of soluble coffee: As not detectable up to $0.010 \mu \mathrm{g} / \mathrm{g}$ and Se not detectable up to $0.005 \mu \mathrm{g} / \mathrm{g}$.

Table 2 - Detection limits for the analytes and conditions of the analytical curve.

\begin{tabular}{cccccc}
\hline Analyte & $\begin{array}{c}\text { Linear } \\
\text { coeficient }\end{array}$ & $\begin{array}{c}\text { Angular } \\
\text { coeficient }\end{array}$ & $\begin{array}{c}\text { Linear } \\
\text { correlation }(\mathbf{r})\end{array}$ & $\begin{array}{c}\text { Instrumental } \\
\text { detection limit }\end{array}$ & $\begin{array}{c}\text { Practical } \\
\text { detection limit }\end{array}$ \\
\hline As & -24.1218 & $5.744 \times 10^{-1}$ & 0.9982 & $1.0 \mu \mathrm{g} / \mathrm{L}$ & $2.0 \mu \mathrm{g} / \mathrm{L}$ \\
Se & -13.8789 & $3.625 \times 10^{-1}$ & 0.9976 & $0.5 \mu \mathrm{g} / \mathrm{L}$ & $1.0 \mu \mathrm{g} / \mathrm{L}$ \\
\hline
\end{tabular}

Table 3 - Results of determination of As and Se in samples of Brazilian soluble coffee ( $\mu \mathrm{g} / \mathrm{g}, \mathrm{n}=3)$

\begin{tabular}{lcc}
\hline \multicolumn{1}{c}{ Sample } & As $(\mu \mathbf{g} / \mathbf{g})$ & Se $(\mu \mathbf{g} / \mathbf{g})$ \\
\hline 1 (Iguaçu lot 04A/96) & $<0.010$ & $<0.005$ \\
2 (Iguaçu lot 04B/96) & $<0.010$ & $<0.005$ \\
3 (Iguaçu lot 09/96) & $<0.010$ & $<0.005$ \\
4 (Ariscafé lot 09/96) & $<0.010$ & $<0.005$ \\
5 (Ariscafé lot 08/96) & $<0.010$ & $<0.005$ \\
6 (Ariscafé lot 09/98) & $<0.010$ & $<0.005$ \\
7 (Ariscafé lot 04/96) & $<0.010$ & $<0.005$ \\
8 (Parmalat lot 08/96) & $<0.010$ & $<0.005$ \\
9 (Do Ponto liofilizado lot 06/96) & $<0.010$ & $<0.005$ \\
10 (Do Ponto descafeinado lot 08/96) & $<0.010$ & $<0.005$ \\
11 (Café Pelé lot 03A/96) & $<0.010$ & $<0.005$ \\
12 (Café Pelé lot 03B/96) & $<0.010$ & $<0.005$ \\
13 (Gran Classic lot 07/96) & $<0.010$ & $<0.005$ \\
14 (Nescafé tradição lot 06/96) & $<0.010$ & $<0.005$ \\
15 (Nescafé tradição lot 02/96) & $<0.010$ & $<0.005$ \\
16 (Nescafé tradição lot 12/96) & $<0.010$ & $<0.005$ \\
17 (Nescafé matinal lot 01/97) & $<0.010$ & $<0.005$ \\
18 (Nescafé matinal lot 06/96) & $<0.010$ & $<0.005$ \\
19 (Bassil coffee lot 09/95) & $<0.010$ & $<0.005$ \\
20 (Eldoro café lot 11/96) & $<0.010$ & $<0.005$ \\
21 (Café diana lot 01/96) & $<0.010$ & $<0.005$ \\
\hline
\end{tabular}

The results for three spiked samples treated as described on sample preparation are shown in the Table 4.

\section{CONCLUSIONS}

The application of the hydride generation technique with inductively coupled plasma atomic emission showed to be suitable to determine arsenic and selenium in soluble coffee with practical detection limits giving values below those specified in Brazilian food legislation (Compêndio da Legislação de Alimentos-Atos do Ministério da Saúde, 1988), that fixed the maximum arsenic content in $1.0 \mu \mathrm{g} / \mathrm{g}$ and selenium in $0.3 \mu \mathrm{g} / \mathrm{g}$. The spiked samples treated as described on sample preparation showed acceptable results, indicating accuracy and precision of the present method of analysis. 
Table 4 - Results of the determination of As and Se in three spiked samples [0.25 $\mu \mathrm{g} / \mathrm{g}$ of the As (V) and Se (IV) was added, $\mathrm{n}=2]$ :

\begin{tabular}{rlcc}
\hline \multicolumn{1}{c}{ Sample } & As & Se \\
& & $\boldsymbol{\mu \mathbf { g } / \mathbf { g }}$ & $\boldsymbol{\mu \mathbf { g } / \mathbf { g }}$ \\
\hline 2 & (Iguaçu lot 04B/96) & $0.27 \pm 0.02$ & $0.25 \pm 0.01$ \\
5 & (Ariscafé lot 08/96) & $0.23 \pm 0.04$ & $0.23 \pm 0.02$ \\
17 & (Bassil coffee lot 09/95) & $0.26 \pm 0.03$ & $0.25 \pm 0.02$ \\
\hline
\end{tabular}

\section{ACKNOWLEDGMENTS}

The financial support from CNPq and FAPESP is greatefully acknowledged.

\section{RESUMO}

O presente trabalho descreve um método para determinação de arsênio e selênio em café solúvel por espectrometria de emissão atômica com plasma acoplado a geração de hidretos, com o objetivo de atender aos limites estabelecidos pela legislação Brasileira de alimentos. Digestões das amostras foram realizadas com ácido nítrico e

hidrogênio em sistema de microondas focalizadas. $\mathrm{O}$ excesso de ácido nítrico foi eliminado através de aquecimento lento e o selênio (VI) foi reduzido a selênio (IV) através de tratamento com ácido $\mathrm{mol} / \mathrm{L}$ e aquecimento a $90{ }^{\circ} \mathrm{C}$ em sistema de refluxo. A influência da acidez na sensibilidade foi investigada, sendo o meio mais estável a concentração de ácido clorídrico de 6 $\mathrm{mol} / \mathrm{L}$. Os limites de determinação foram de 2.0 $\mu \mathrm{g} / \mathrm{L}$ para o As e $1.0 \mu \mathrm{g} / \mathrm{L}$ para o Se. Os resultados das amostras enriquecidas demonstram a precisão e exatidão do método proposto.

\section{REFERENCES}

Brimmer S. P.; Fawcett W. R. and Kulhavy K. A. (1987), Quantitative Reduction of Selenate Ion to Selenite in Aqueous Samples. Anal. Chem., 59, 1470-1471

Compêndio da Legislação de Alimentos - Atos do Ministério da Saúde (1988), In: Aditivos Incidentais tabela II, v.1, cap.3, resolução $\mathrm{n}^{\circ} 4$.

Clarke R. J. and Walker L. J. (1974), Potassium and and Other Mineral Contents of Green,
Roasted and Instant Coffees. J. Sci. Fd Agric., 25, 1389-1404

Gillies M. E. and Birkbeck J. A. (1983), Tea and Coffee as Sources of Some Minerals in the New Zealand Diet. Am. J. Clin. Nutr., 38, 936-942

Goulden P. D.; Anthony D. H. J. and Austen K. D. (1981), Determination of Arsenic and Selenium in Water, Fish, and Sediments by Inductively Coupled Argon Plasma Emission Spectrometry. Anal. Chem., 53, 2027-2029

Horwitz C. and Van Der Linden S. E. (1974), Cadmium and Cobalt in Tea and Coffee and their Relationship to Cardiovascular Disease. S. Afr. Med. J., 48, 230-233

Krivan V.; Barth P. and Morales A. (1993), Multielement Analysis of Green Coffee and its Possible use for the Determination of Origin. Mikrochim. Acta, 110, 217-236

Kuennen R. W.; Hahn M. H.; Fricke F. L. and Wolnik K. A. (1982), Hydride Generation and Condensation Flame Atomic Absorption Spectroscopic Determination of Antimony in Raw Coffee Beans and Processed Coffee. J.Assoc. Off. Anal. Chem., 65 (5), 1146-1149

Kapur J. K. and West T. S. (1974), Determination of Lead in Instant Coffee and Tea Powders by Carbon Filament Atomic Absorption Spectrometry. Anal. Chim. Acta, 73, 180-184

Koch K. R.; Bruno Pougnet M. A. and De Villiers S. (1989), Determination of Aluminium Leves in Tea and Coffee by Inductively Coupled Plasma Optical Emission Spectrometry and Graphite Furnace Atomic Absorption Spectrometry. Analyst, 114, 911-913

Lara W. H.; Toledo M. and Takahashi M. Y. (1975/76), Teores de Cobre em Café Torrado e 35/36, 17-22 Rev. Inst. Adolfo Lutz,

Nakahara T. (1981), Application of Hydride Generation to the Determination of Trace Concentrations of Arsenic by Inductively Coupled Plasma Atomic Emission Spectrometry. Anal. Chim. Acta, 131, 73-82 
Nygaard D. D. and Lowry J. H. (1982), Sample Digestion Procedures for Simultaneous Determination of Arsenic, Antimony, and Selenium by Inductively Coupled Argon Plasma Emission Spectrometry with Hydride Generation. Anal. Chem., 54, 803- 807

Nakahara T. and Kikui N. (1985), Determination of trace Concentrations of Selenium by Continuous Hydride Generation- Inductively Coupled Plasma Atomic Emission Spectrometry. Spectrochim Acta, 40B (1/2), 21-28

Oliveira E.; McLaren J. W. and Berman S. S. (1983), Simultaneous Determination of Arsenic, Antimony, and Selenium in Marine Samples by Inductively Coupled Plasma Atomic Emission Spectrometry. Anal. Chem., 55 (13), 2047-2050

Pahlavanpour B.; Thompson M. and Thorne L. (1980), Simultaneous Determination of Trace Concentrations of Arsenic, Antimony and Bismuth in Soils and Sediments by Volatile Hydride Generation and Inductively Coupled Plasma Emission Spectrometry. Analyst, 105, 756-761

Santos E. J. and Oliveira E. (1997), Avaliação e Definição de Procedimento de Mineralização de Amostras de Café Solúvel para Determinação de
Nutrientes e Contaminantes Inorgânicos por ICPAES. Arq. Biol. Tecnol., 40 (3), 632-641

Silva P. (1996), O Mercado de Café no Brasil. Alimentos \& Tecnologia, 64, 26-30

Thompson M. (1987), Inductively Coupled Plasmas in in Analytical Atomic Spectrometry. In: Montaser Montaser A., Golightly D. W. ed. Analytical Performance of Inductively Coupled Plasma Atomic Emission Spectrometry. New York. VHC Publisher, 163-198

Ybanez N.; Cervera M. L. and Montoro R. (1992), Determination of Arsenic in Dry Ashed Seafood Products by Hydride Generation Atomic Absorption Spectrometry and a Critical Comparative Study with Platform Furnace Zeeman - effect Atomic Absorption Spectrometry and Inductively Coupled Plasma Atomic Emission Spectrometry. Anal. Chim. Acta, 258, 61-71

Received: April 04, 2000;

Revised: June 27, 2000; Accepted: November 23, 2000. 